International Scientific Organization http://iscientific.org/

Chemistry International

www.bosaljournals.com/chemint/

\title{
Mineral contents of Ethiopian red and green apple fruits: A comparison with WHO/FAO standards
}

\section{Demisew Jemaneh and Bhagwan Singh Chandravanshi*}

\author{
Department of Chemistry, College of Natural and Computational Sciences, Addis Ababa University, P.O. Box 1176, Addis \\ Ababa, Ethiopia \\ *Corresponding author's E. mail: bscv2006@yahoo.com
}

\section{A R T I C L E I N F O}

\section{Article type:}

Research article

Article history:

Received October 2020

Accepted February 2021

April 2021 Issue

\section{Keywords:}

Apple fruit

Red apple

Green apple

Essential minerals

Non-essential minerals

Ethiopia

\section{A B S T R A C T}

The aim of this study was to evaluate the macro- and micro essential and nonessential minerals in apple fruits collected from farmland in Wollega, Chencha, Ankober (Ethiopia) and Addis Ababa which are imported to Ethiopia from South Africa and Israel. Samples were wet-digested using $3 \mathrm{~mL} \mathrm{HNO}_{3}$ and $1 \mathrm{~mL} \mathrm{HClO}_{4}$ for 2:15 hours at $210^{\circ} \mathrm{C}$. Selected metals (Mg, Ca, Fe, Mn, Cu, Al, Zn, Cr, Co, Ni, Cd and $\mathrm{Pb}$ ) were determined by microwave plasma-atomic emission spectroscopy. The validity of optimized procedure was evaluated by the analysis of spiked samples and recoveries were in $90.8-106 \%$ range. The mean concentration range $(\mathrm{mg} / \mathrm{kg})$ of metal in fruit samples were Ca (1065-36275, 1013-36143), Mg (27153, 78.3-139), Fe (103-276, 123-241), Mn (13.5-13.7, 11.5-16.3), Cu (5.13-6.56, 4.11-12.6), Al (77.8-129, 52.5-89.6), Zn (41.3-73.6, 47.4-54.4), Cr (6.15-10.04, 6.57-7.14), Co (6.57-7.14, 1.70-2.35), Ni (1.33-2.37, 1.43-7.66), respectively. Cd and $\mathrm{Pb}$ were not detected. Analysis of variance showed significant difference $(\mathrm{p}=$ 0.05) in the levels of $\mathrm{Cu}, \mathrm{Al}$ and $\mathrm{Co}$ among sampling sites in green apple fruit while all the other metals did not show significance difference. Red apple fruit showed a significance difference in the levels of $\mathrm{Fe}, \mathrm{Mn}, \mathrm{Cu}, \mathrm{Zn}, \mathrm{Cr}$ and $\mathrm{Co}$ metal while the other metals showed insignificance differences. Pearson correlation coefficients indicated strong, moderate and weak correlation between different pairs of metals in both the green and red apples.

(c) 2021 International Scientific Organization: All rights reserved.

Capsule Summary: The macro- and micro essential and non-essential minerals in apple fruits collected from farmland in Wollega (Ethiopia) and market in Addis Ababa which are imported to Ethiopia from South Africa and Israel were evaluated.

Cite This Article As: D. Jemaneh and B. S. Chandravanshi. Mineral contents of Ethiopian red and green apple fruits: A comparison with WHO/FAO standards. Chemistry International 7(2) (2021) 112-122.

https://doi.org/10.5281/zenodo.4572213

\section{INTRODUCTION}

Apple tree (Malus pumila) is a member of Rosaceae family. Its fruits mature on shoots that are more than two years old. They mature in late summer or autumn depending on the variety. Apple trees are cultivated worldwide. Apple is a king of all fruits. It is a sweet and edible fruit. It is one of the most favorite and popular fruits ever known. Fruits are essential part of modern diet in almost every society. Fruits and fruit products are known to be good source of nutrients such as minerals and vitamins (Nahar et al., 1990). Fruit juices are 
available in most part of the world in bottles, cans, cups, laminated paper packs and almost every other form of packing in the diet of most people irrespective of age. Thus, it contributes to good health (Tasnim et al., 2010).

Fruit juices deserve special attention because of their important influence on human health. Intake of fruit juices has been constantly related with reduced risk of many cancer types (Brock et al., 1988) and might be protective against stroke (Feldman, 2001) and hold up the beginning of Alzheimer's disease (Dai et al., 2006). The widespread and growing intake of apples and apple juice/products and their rich phytochemical profiles suggest their important potential to affect the health of the populations consuming them.

Apple fruits are extremely rich in important antioxidants, flavonoids and dietary fibers. The phytonutrients and antioxidants in apple fruits help to reduce the risk of developing cancer, improve neurological health, prevent dementia, reduce the risk of stroke, lowering levels of bad cholesterol, reducing risk of diabetes. Apple fruits also contain pectin which helps bulk up to the stool to treat diarrhea and constipation and also contain some chemicals that seem to be able to kill bacteria, reduce swelling in the body and kill the cancer cell (Brock et al., 1988; Feldman, 2001; Dai et al., 2006).

All parts of the apple fruit, including the skin, except seeds, are suitable for human consumption. The core, from stem to bottom, containing the seeds, is usually not eaten and is discarded. Apple fruits can be consumed in various ways: juice, raw in salads, baked in pies, cooked into sauces and spreads like apple butter, and other baked dishes. Several techniques are used to preserve apple fruits and apple fruit products. Apple fruits can be canned, dried or frozen. Canned or frozen apples are eventually baked into pies or other cooked dishes. Apple juice is also bottled. Apple juice is often concentrated and frozen.

There are many variety of apples found across the world. In fact there are more than 7500 varieties of apples grown around the world. Even though there are thousands of different varieties of apples they appear mainly in four different colors namely red, pink, yellow and green. Green apples have low sugar and calorie content to make them strong contender in the list of healthy super foods. From its benefits one is increasing the platelet count and weight management because of its antioxidant rich content and antiinflammatory nature (Kent, 2017). Red apple contains the flavonoids and pigment anthocyanins which gives its red color. Red apples are more sweet and popular than green apples. Red delicious and Fuji are common examples of red apples (Kent, 2017). Green apples have mostly sour taste, but red apples have sweeter taste. Green apple may contain slightly more fiber and less carbohydrates and sugar than red apples. By oxidants red apples is more preferable, because it is rich in antioxidants, pectin, quercetin and flavonoids to protect cell from oxidative damage. The macronutrient balance of green apple is healthier than red apple.

In Ethiopia consumption of apple fruits is increasing from time to time. As a tradition in Ethiopia people eat apple fruits without knowing the permissible limit of metals. Metals like cadmium, lead and arsenic have a toxic property, even kill a person and some other metal also cause a disease when they are above permissible limit. All trace elements are toxic if consumed at sufficiently high levels for long enough periods. The difference between toxic intakes and optimal intakes to meet physiological needs for essential trace elements is high for some elements, but is much lower for others elements.

Several studies have been reported on the mineral contents of apple fruits in different parts of the world. Webster (1981) has studied the mineral composition of apple fruits and relationships between and within peel, cortex and whole fruit samples. Leis et al. (2003) have reported the mineral content of apple fruits and leaves. Casero et al. (2009) have investigated the interrelation between fruit mineral content and pre-harvest calcium treatments on 'golden smoothee' apple quality. Fatih and Özcan (2010) have reported the chemical compositional properties and mineral contents of some apple cultivars. Lee (2012) has studied the common nutrients and nutraceutical quality of apples. Nava et al. (2018) have studied the mineral composition of leaves and fruits of apple 'Fuji'. Resmije et al. (2019) have investigated the distribution of heavy metals in apple tissues grown in the soils of industrial area. Sachini et al. (2020) have reported the mineral contents in the skin and flesh of fruits of apple cultivars.

In Ethiopia a few studies have been done on the mineral contents of fruits of cactus pear (Aregahegn et al., 2013), fennel (Endalamaw and Chandravanshi, 2015), banana, grape, guava, mandarin and orange (Yami et al., 2016) and seeds of korarima (Mekassa and Chandravanshi, 2015) and fenugreek (Hagos and Chandravanshi, 2016). However, there is no study on the mineral contents of Ethiopian apple fruits. Therefore, it is worthwhile to determine the levels of metals in the apple fruits cultivated in Ethiopia and also in the imported apple fruits to Ethiopia.

The objective of this study was to determine the levels of macro ( $\mathrm{Mg}$ and $\mathrm{Ca}$ ), micro ( $\mathrm{Zn}, \mathrm{Fe}, \mathrm{Cu}, \mathrm{Mn}, \mathrm{Co}, \mathrm{Cr}, \mathrm{Ni}$ ) and toxic $(\mathrm{Pb}$ and $\mathrm{Cd})$ metals in apple fruits from the plants cultivated in three selected area of Ethiopia and apple fruits imported to Addis Ababa, Ethiopia from Israel and South Africa and to compare the levels of metals in apple fruits with WHO/FAO maximum permissible levels.

\section{MATERIAL AND METHODS}

\section{Apparatus and equipment}

Polyethylene plastic bags were used to collect the harvested apple fruit samples. A drying-oven (Digitheat, J. P. Selecta, Spain) was used to dry apple fruit samples. A ceramic mortar and pestle (USA) was used to ground the apple fruit samples. A digital analytical balance (Mettler Toledo, Model AG204, Switzerland) with $\pm 0.0001 \mathrm{~g}$ precision was used to weigh apple fruit samples. $250 \mathrm{~mL}$ round bottom flasks fitted with reflux condensers were used in Kjeldahl (England) apparatus 
to digest the dried and powdered apple fruits. A refrigerator (Hitachi, Tokyo, Japan) was used to keep the digested samples until analysis. Agilent model 4200 (USA) microwave plasma-atomic emission spectrometer (MP-AES) was used for the determination of the metals $(\mathrm{K}, \mathrm{Mg}, \mathrm{Ca}, \mathrm{Fe}, \mathrm{Mn}, \mathrm{Zn}, \mathrm{Cu}$, $\mathrm{Co}, \mathrm{Cr}, \mathrm{Ni}, \mathrm{Pb}, \mathrm{Cd}$ ) in the apple fruits.
Sigma Aldrich, Steinleim, Germany) were used for the digestion of apple fruits. Strontium nitrate (98\%, Aldrich Muwaukee, USA) was used to avoid refractory interference (for releasing calcium and magnesium from their phosphates). Stock standard solutions containing $1000 \mathrm{mg} / \mathrm{L}$ in $2 \% \mathrm{HNO}_{3}$ of the metals $\mathrm{K}, \mathrm{Mg}, \mathrm{Ca}, \mathrm{Fe}, \mathrm{Mn}, \mathrm{Zn}, \mathrm{Cu}, \mathrm{Co}, \mathrm{Cr}, \mathrm{Ni}$,

Table 1: Optimization of digestion procedure for $0.5 \mathrm{~g}$ apple fruit

\begin{tabular}{|c|c|c|c|}
\hline $\begin{array}{l}\text { Volume ratio } \\
\left(\mathrm{HNO}_{3}: \mathrm{HClO}_{4}\right)\end{array}$ & $\begin{array}{l}\text { Digestion temperature } \\
\qquad\left({ }^{\circ} \mathrm{C}\right)\end{array}$ & Digestion time $(\mathrm{h})$ & Observation \\
\hline $5: 1$ & 2700 & $3: 00$ & Colorless \\
\hline $4: 1$ & 270 & $3: 00$ & Colorless \\
\hline $3: 1$ & 270 & $3: 00$ & Clear colorless solution \\
\hline $3: 2$ & 270 & $3: 00$ & Colorless \\
\hline $2: 2$ & 270 & $3: 00$ & Colorless \\
\hline $3: 1$ & 120 & 3:00 & Colorless \\
\hline $3: 1$ & 150 & $3: 00$ & Colorless \\
\hline $3: 1$ & 180 & $3: 00$ & Colorless \\
\hline $3: 1$ & 210 & 3:00 & Clear colorless solution \\
\hline $3: 1$ & 240 & $3: 00$ & Colorless \\
\hline $3: 1$ & 180 & $3: 00$ & Colorless \\
\hline $3: 1$ & 210 & $3: 00$ & Clear colorless solution \\
\hline $3: 1$ & 240 & $3: 00$ & Colorless \\
\hline $3: 1$ & 270 & $3: 00$ & Colorless \\
\hline
\end{tabular}

Table 2: The wavelength, concentrations of the standards, calibration equation and correlation coefficient value of the calibration curve for the determination of metals in apple fruits

\begin{tabular}{ccccc}
\hline Metals & $\begin{array}{c}\text { Wavelength } \\
(\mathrm{nm})\end{array}$ & $\begin{array}{c}\text { Concentration of standards } \\
(\mathrm{mg} / \mathrm{L})\end{array}$ & $\begin{array}{c}\text { Correlation } \\
\text { coefficient }\end{array}$ & Calibration equation \\
\hline $\mathrm{Ca}$ & 422.7 & $0,5,10,15,20$ & 0.998 & $\mathrm{y}=67343 \mathrm{x}+21867$ \\
$\mathrm{Mg}$ & 279.553 & $0,0.5,1.0,2.0,4.0$ & 0.999 & $\mathrm{y}=19334 \mathrm{x}+1884$ \\
$\mathrm{Fe}$ & 371.99 & $0,5,10,15,20$ & 0.998 & $\mathrm{y}=5626 \mathrm{x}-3868$ \\
$\mathrm{Mn}$ & 259.372 & $0,0.5,1.0,2.0,4.0$ & 0.999 & $\mathrm{y}=2977 \mathrm{x}+206.3$ \\
$\mathrm{Cu}$ & 327.395 & $0,0.5,1.0,2.0,4.0$ & 0.999 & $\mathrm{y}=33562 \mathrm{x}+525.3$ \\
$\mathrm{Al}$ & 396.152 & $0,0.5,1.0,2.0,4.0$ & 0.999 & $\mathrm{y}=24298 \mathrm{x}+759.3$ \\
$\mathrm{Zn}$ & 213.857 & $0,0.5,1.0,2.0,4.0$ & 0.999 & $\mathrm{y}=4541 \mathrm{x}+301.9$ \\
$\mathrm{Cr}$ & 427.480 & $0,0.5,1.0,2.0,4.0$ & 0.994 & $\mathrm{y}=327.3 \mathrm{x}+50.34$ \\
$\mathrm{Co}$ & 340.512 & $0,0.5,1.0,2.0,4.0$ & 0.996 & $\mathrm{y}=5444 . \mathrm{x}+178.5$ \\
$\mathrm{Ni}$ & 305.081 & $0,0.5,1.0,2.0,4.0$ & 0.999 & $\mathrm{y}=4453 \mathrm{x}+207.2$ \\
$\mathrm{~Pb}$ & 368.346 & $0,0.5,1.0,2.0,4.0$ & 0.999 & $\mathrm{y}=2616 \mathrm{x}+108.9$ \\
$\mathrm{Cd}$ & 226.502 & $0,0.5,1.0,2.0,4.0$ & 0.998 & $\mathrm{y}=660.3 \mathrm{x}+118.9$ \\
\hline
\end{tabular}

\section{Reagents and chemicals}

All the reagents used in this study were of analytical grade. $\mathrm{HNO}_{3}$ (69-72\%, Spectrosol, BDH, England) and $\mathrm{HClO}_{4}$ (70\%,
Pb, Cd (Buck Scientific Puro-Graphictm, USA) were used for the preparation of calibration standards and in the spiking experiments. Distilled deionized water was used throughout the experiment. 
Table 3: Method detection limit and limit of quantification of metals in apple fruit

\begin{tabular}{ccc}
\hline Metal & LOD $(\mathrm{mg} / \mathrm{kg})$ & LOQ $(\mathrm{mg} / \mathrm{kg})$ \\
\hline $\mathrm{Ca}$ & 4.3 & 14.3 \\
$\mathrm{Mg}$ & 3.6 & 12 \\
$\mathrm{Fe}$ & 2.6 & 8.7 \\
$\mathrm{Mn}$ & 1.3 & 4.3 \\
$\mathrm{Cu}$ & 0.6 & 2 \\
$\mathrm{Al}$ & 4.4 & 14.6 \\
$\mathrm{Zn}$ & 2.2 & 7.4 \\
$\mathrm{Cr}$ & 0.51 & 1.7 \\
$\mathrm{Co}$ & 4.2 & 14 \\
$\mathrm{Ni}$ & 0.57 & 1.9 \\
$\mathrm{~Pb}$ & BDL & BDL \\
$\mathrm{Cd}$ & BDL & BDL
\end{tabular}

$\mathrm{BDL}=$ Below detection limit

Table 4: Concentration of metals (mean $\pm \mathrm{SD})(\mathrm{mg} / \mathrm{kg})$ in green apple fruits

\begin{tabular}{cccc}
\hline Metal & \multicolumn{3}{c}{ Concentration of metals $($ mean \pm SD) $(\mathrm{mg} / \mathrm{kg})$} \\
\cline { 2 - 4 } & Ankober & South Africa & Wollega \\
\hline $\mathrm{Ca}$ & $1125 \pm 104$ & $36275 \pm 3024$ & $1065 \pm 60$ \\
$\mathrm{Mg}$ & $27.0 \pm 1.7$ & $153 \pm 10$ & $71.2 \pm 6.5$ \\
$\mathrm{Fe}$ & $162 \pm 12$ & $276 \pm 10$ & $103 \pm 6$ \\
$\mathrm{Mn}$ & $13.5 \pm 1.1$ & $13.5 \pm 0.9$ & $13.7 \pm 0.7$ \\
$\mathrm{Cu}$ & $6.56 \pm 1.06$ & $5.77 \pm 0.46$ & $5.13 \pm 0.30$ \\
$\mathrm{Al}$ & $88.1 \pm 8.1$ & $129 \pm 10$ & $77.8 \pm 4.0$ \\
$\mathrm{Zn}$ & $41.3 \pm 3.67$ & $73.6 \pm 2.52$ & $49.7 \pm 4.13$ \\
$\mathrm{Cr}$ & $6.15 \pm 0.13$ & $10.04 \pm 0.79$ & $8.57 \pm 0.61$ \\
$\mathrm{Co}$ & $2.48 \pm 0.13$ & $2.48 \pm 0.20$ & $1.85 \pm 0.10$ \\
$\mathrm{Ni}$ & $1.33 \pm 0.07$ & $2.37 \pm 0.05$ & $1.38 \pm 0.11$ \\
$\mathrm{~Pb}$ & $\mathrm{ND}$ & $\mathrm{ND}$ & $\mathrm{ND}$ \\
$\mathrm{Cd}$ & $\mathrm{ND}$ & $\mathrm{ND}$ & $\mathrm{ND}$ \\
\hline
\end{tabular}

$\mathrm{ND}=$ Not detected

\section{Description of sampling sites}

The sampling locations were chosen near farmland. The red and green apple fruits were collected from Wollega, Ankober around Debre Birhan and Chencha District in Arbaminch (Ethiopia). The location of sample collected from Arbaminch is a place where there is large cultivation of apple plants especially in Chencha. Chencha District is a place which is far from Arbaminch by $16 \mathrm{~km}$. Chencha's climate is classified as warm and temperate and there is significant rainfall throughout the year. The average annual temperature of this place is $14{ }^{\circ} \mathrm{C}$ and the average rainfall is $1353 \mathrm{~mm}$. The second sample site is Ankober, a place which is far from Addis Ababa by $170 \mathrm{~km}$ and the third sample site is Debre Birhan, $42 \mathrm{~km}$ from Addis Ababa. Its annual rainfall range is 1000 to $1400 \mathrm{~mm}$. The red and green apple fruits were also collected from the market in Addis Ababa, which are imported to Ethiopia from South Africa and Israel.

\section{Collection and preparation of apple fruits samples}

The apple fruits from the plants were collected manually using vinyl gloves for protecting hands. The bruised portions were removed and the remaining samples packed in the polyethylene bags and transported to the analytical laboratory of Chemistry Department, Addis Ababa University. The fruit samples were washed with tap water and with double distilled water to eliminate adsorbed dust and particulate matters. The fruit samples were chopped into small pieces using a plastic knife in order to facilitate drying. The samples were air dried for a week and further dried in a hot air oven at $50-60{ }^{\circ} \mathrm{C}$ for $24 \mathrm{~h}$ to remove moisture and maintain constant mass. The dried samples were ground into powder using mortar and pestle and sieved to $0.425 \mathrm{~mm}$ mesh size. The sieved samples were stored in the polyethylene bags and kept in desiccators until the time of digestion. 
Table 5: Concentration of metals (mean \pm SD) $(\mathrm{mg} / \mathrm{kg})$ in red apple fruit

\begin{tabular}{lccc} 
Metal & \multicolumn{3}{c}{ Concentration of metals (mean \pm SD) $(\mathrm{mg} / \mathrm{kg})$} \\
\cline { 2 - 4 } & Arbaminch & Israel & Wollega \\
\cline { 2 - 4 } $\mathrm{Ca}$ & $36143 \pm 3153$ & $1013 \pm 35$ & $2444 \pm 140$ \\
$\mathrm{Fe}$ & $78.3 \pm 4.8$ & $139 \pm 5$ & $78.7 \pm 6.5$ \\
$\mathrm{Mn}$ & $129 \pm 10$ & $241 \pm 15$ & $123 \pm 5$ \\
$\mathrm{Cu}$ & $15.3 \pm 0.7$ & $11.5 \pm 1.0$ & $16.3 \pm 1.5$ \\
$\mathrm{Al}$ & $7.94 \pm 0.23$ & $4.11 \pm 0.24$ & $12.6 \pm 1.13$ \\
$\mathrm{Zn}$ & $68.9 \pm 2.1$ & $52.5 \pm 1.5$ & $89.6 \pm 8.1$ \\
$\mathrm{Cr}$ & $47.4 \pm 1.9$ & $54.4 \pm 4.5$ & $51.3 \pm 3.8$ \\
$\mathrm{Co}$ & $7.14 \pm 0.18$ & $6.57 \pm 0.61$ & $6.57 \pm 0.41$ \\
$\mathrm{Ni}$ & $2.35 \pm 0.17$ & $2.28 \pm 0.23$ & $1.70 \pm 0.04$ \\
$\mathrm{~Pb}$ & $1.43 \pm 0.08$ & $7.66 \pm 0.51$ & $1.78 \pm 0.12$ \\
$\mathrm{Cd}$ & $\mathrm{ND}$ & $\mathrm{ND}$ & $\mathrm{ND}$ \\
$\mathrm{ND}$ & $\mathrm{ND}$ & $\mathrm{ND}$ & $\mathrm{ND}$
\end{tabular}

ND - Not detected.

Table 6: Metals concentration $(\mathrm{mg} / \mathrm{kg})$ in the green and red apple fruits

\begin{tabular}{lcc}
\hline Metal & \multicolumn{2}{c}{ Range of metal concentration $(\mathrm{mg} / \mathrm{kg})$} \\
\cline { 2 - 3 } & Green apple fruit & Red apple fruit \\
\hline $\mathrm{Ca}$ & $1065-36275$ & $1013-36143$ \\
$\mathrm{Mg}$ & $27-153$ & $78.3-139$ \\
$\mathrm{Fe}$ & $103-276$ & $123-241$ \\
$\mathrm{Mn}$ & $13.5-13.7$ & $11.5-16.3$ \\
$\mathrm{Cu}$ & $5.13-6.56$ & $4.11-12.6$ \\
$\mathrm{Al}$ & $77.8-129$ & $52.5-89.6$ \\
$\mathrm{Zn}$ & $41.3-73.6$ & $47.4-54.4$ \\
$\mathrm{Cr}$ & $6.15-10.04$ & $6.57-7.14$ \\
$\mathrm{Co}$ & $1.85-2.48$ & $1.70-2.35$ \\
$\mathrm{Ni}$ & $1.33-2.37$ & $1.43-7.66$ \\
\hline
\end{tabular}

\section{Optimization of the digestion procedure}

Different digestion procedures for the apple fruits were carried out using $\mathrm{HNO}_{3}$ and $\mathrm{HClO}_{4}$ mixtures by varying volume of the acid mixture, digestion time and digestion temperature. A $0.5 \mathrm{~g}$ of powdered sample was weighed and transferred to $250 \mathrm{~mL}$ of round bottom flask. To this different volumes of $\mathrm{HNO}_{3}$ and $\mathrm{HClO}_{4}$ at specified proportions (v/v) was added and digested at temperatures $120,150,180,210$, 240,270 and at different duration of time which is 1:45, 2:00, $2: 15,2: 30,2: 45,3: 00$ hour. Optimized procedures were selected based on the usage of lesser reagent volume, shorter digestion time and reasonable mild temperature for obtaining clear and colorless solutions of the resulting digests. The digested solutions were cooled for $5 \mathrm{~min}$ on Kjeldal apparatus after it was switched off and cooled for 5 min outside of the apparatus. $5 \mathrm{~mL}$ of distilled water was added to dissolve the precipitate formed on cooling and gently shake and filtered into $50 \mathrm{~mL}$ volumetric flask through filter paper. Then the clear solution was diluted up to $50 \mathrm{~mL}$ with distilled water and stored for analysis by MP-AES. The optimized parameters for digestion procedure were 3:1 of $\mathrm{HNO}_{3}$ and $\mathrm{HClO}_{4}$ at $210{ }^{\circ} \mathrm{C}$ and for 2:15 hours. The results are summarized in Table 1.

\section{Digestion of the apple fruits}

A $0.5 \mathrm{~g}$ of powdered samples were weighed and transferred to $250 \mathrm{~mL}$ of round bottom flask. To do this $4 \mathrm{~mL}$ of $3: 1(\mathrm{v} / \mathrm{v})$ $\mathrm{HNO}_{3}$ and $\mathrm{HClO}_{4}$ was added and digested at $210{ }^{\circ} \mathrm{C}$ for $2: 15 \mathrm{~h}$ for all the apple fruit sample, separately. The digested solution was allowed to cool and $5 \mathrm{~mL}$ distilled water was added to dissolve the precipitate formed on cooling and gently swirled and filter into $50 \mathrm{~mL}$ volumetric flask through filter paper. The clear solution obtained was diluted up to 50 $\mathrm{mL}$ with distilled water. Each type of apple fruit samples were digested in triplicate. Digestion of reagent blank was also performed in parallel with the samples. All the solutions were stored in tightly capped polyethylene bottles and stored in a refrigerator until analysis. 
Table 7: Pearson correlation coefficients between metals concentration in green apple fruits

\begin{tabular}{lllllllllll}
\hline & $\mathrm{Ca}$ & $\mathrm{Mg}$ & $\mathrm{Fe}$ & $\mathrm{M} \mathrm{n}$ & $\mathrm{Cu}$ & $\mathrm{Al}$ & $\mathrm{Zn}$ & $\mathrm{Cr}$ & $\mathrm{Co}$ & $\mathrm{Ni}$ \\
\hline $\mathrm{Ca}$ & 1.00 & & & & & & & & & \\
$\mathrm{Mg}$ & 0.93 & 1.00 & & & & & & & & \\
$\mathrm{Fe}$ & 0.94 & 0.77 & 1.00 & & & & & & & \\
$\mathrm{M} \mathrm{n}$ & -0.5 & 0.17 & 0.76 & 1.00 & & & & & & \\
$\mathrm{Cu}$ & 0.06 & -0.4 & 0.27 & 0.83 & 1.00 & & & & & \\
$\mathrm{Al}$ & 0.98 & 0.86 & 0.98 & -.66 & 0.13 & 1.00 & & & \\
$\mathrm{Zn}$ & 0.96 & 1 & 0.82 & -0.2 & 031 & 0.9 & 1.00 & & & \\
$\mathrm{Cr}$ & 0.78 & 0.95 & 0.53 & 0.14 & 0.66 & 0.66 & 0.92 & 1.00 & & \\
$\mathrm{Co}$ & 0.50 & 0.17 & 0.76 & -1 & 0.83 & 0.66 & 0.27 & 0.14 & 1.00 & \\
$\mathrm{Ni}$ & 0.99 & 0.95 & 0.92 & 0.46 & -0.1 & 0.97 & 0.98 & 0.81 & 0.46 & 1.00 \\
\hline
\end{tabular}

Table 8: Pearson correlation coefficients between metals concentration in red apple fruits

\begin{tabular}{lllllllllll}
\hline & $\mathrm{Ca}$ & $\mathrm{Mg}$ & $\mathrm{Fe}$ & $\mathrm{M} \mathrm{n}$ & $\mathrm{Cu}$ & $\mathrm{Al}$ & $\mathrm{Zn}$ & $\mathrm{Cr}$ & $\mathrm{Co}$ & $\mathrm{Ni}$ \\
\hline $\mathrm{Ca}$ & 1.00 & & & & & & & & & \\
$\mathrm{Mg}$ & -0.53 & 1.00 & & & & & & & & \\
$\mathrm{Fe}$ & -0.49 & 0.99 & 1.00 & & & & & & & \\
$\mathrm{M} \mathrm{n}$ & 0.35 & -0.97 & -0.98 & 1.00 & & & & & \\
$\mathrm{Cu}$ & -0.02 & -0.83 & -0.86 & 0.92 & 1.00 & & & & \\
$\mathrm{Al}$ & -0.03 & -0.82 & -0.85 & 0.92 & 0.99 & 1.00 & & & \\
$\mathrm{Zn}$ & -0.91 & 0.83 & 0.80 & -0.70 & -0.39 & -0.38 & 1.00 & & \\
$\mathrm{Cr}$ & 0.99 & -0.50 & -0.46 & 0.31 & -0.05 & -0.06 & -0.89 & 1.00 & & \\
$\mathrm{Co}$ & 0.55 & 0.40 & 0.45 & -0.58 & -0.84 & -0.84 & -0.16 & 0.58 & 1.00 & \\
$\mathrm{Ni}$ & -0.57 & 0.99 & 0.99 & -0.96 & -0.80 & -0.80 & 0.85 & -0.54 & 0.36 & 1.00 \\
\hline
\end{tabular}

Table 9: Analysis of variance (ANOVA) within samples of the green apple fruits

\begin{tabular}{lllllllllll}
\hline Parameters & \multicolumn{9}{c}{ Metals compared at $95 \%$ confidence level } \\
\cline { 2 - 12 } & $\mathrm{Ca}$ & $\mathrm{Mg}$ & $\mathrm{Fe}$ & $\mathrm{Mn}$ & $\mathrm{Cu}$ & $\mathrm{Al}$ & $\mathrm{Zn}$ & $\mathrm{Cr}$ & $\mathrm{Co}$ & $\mathrm{Ni}$ \\
\hline $\mathrm{F}_{\text {critical }}$ & 9.55 & 5.14 & 9.55 & 5.14 & 5.14 & 9.55 & 5.14 & 5.14 & 9.55 & 5.14 \\
$\mathrm{~F}_{\text {calculated }}$ & 266 & 263 & 314 & 13.3 & 3.17 & 17.4 & 55.16 & 30.9 & 4.8 & 137 \\
p-value & 0.00042 & 0.0000014 & 0.00033 & 0.006 & 0.11 & 0.2 & 0.00014 & 0.00069 & 0.11 & 0.0000098 \\
\hline
\end{tabular}

Table 10: Analysis of variance (ANOVA) within samples of red apple fruits

\begin{tabular}{lllllllllll}
\hline Parameters & \multicolumn{9}{l}{ Metals compared at 95\% confidence level } \\
\cline { 2 - 11 } & $\mathrm{Ca}$ & $\mathrm{Mg}$ & $\mathrm{Fe}$ & $\mathrm{Mn}$ & $\mathrm{Cu}$ & $\mathrm{Al}$ & $\mathrm{Zn}$ & $\mathrm{Cr}$ & $\mathrm{Co}$ & $\mathrm{Ni}$ \\
\hline $\mathrm{F}_{\text {critical }}$ & 9.55 & 5.14 & 9.55 & 5.14 & 5.14 & 9.55 & 5.14 & 5.14 & 9.55 & 5.14 \\
$\mathrm{~F}_{\text {calculated }}$ & 118 & 129 & 48.8 & 13.35 & 0.024 & 58.7 & 2.32 & 1.72 & 6.6 & 348 \\
p-value & 0.00139 & 0.0000012 & 0.005 & 0.006 & 0.97 & 0.0039 & 0.17 & 0.25 & 0.079 & 0.00000047
\end{tabular}




\section{Calibration}

A $100 \mathrm{mg} / \mathrm{L}$ standard solution was prepared from standard stock solutions that contained $1000 \mathrm{mg} / \mathrm{L}$. The $100 \mathrm{mg} / \mathrm{L}$ standard solution was diluted with distilled water to obtain four working standards for each metal of interest. The calibration curves and correlation coefficients of each of elements were determined by plotting the concentration of metals versus their corresponding emission intensity. The correlation coefficients of the calibration curves were $>0.99$ which indicated a good relationship between emission intensity and concentration of metals. The metals $\mathrm{Ca}, \mathrm{Mg}, \mathrm{Fe}$, $\mathrm{Mn}, \mathrm{Cu}, \mathrm{Zn}, \mathrm{Cr}, \mathrm{Co}, \mathrm{Ni}, \mathrm{Pb}, \mathrm{Cd}$ were determined by microwave plasma-atomic emission spectroscopy (MP-AES). Triplicate analysis was done on each sample. The results were expressed as mean with standard deviation of the triplicate measurements. Concentrations of the working standards, calibration equation and correlation coefficient value of the calibration curve for each of the metals are listed in Table 2.

\section{Detection limit and quantification limit}

The detection limit is the lowest concentration or weight of analyte that can be measured at a specific confidence level. The limit of detection is expressed as three times of blank standard deviation and limit of quantification is expressed as ten times of blank standard deviation. In this study six blank samples were digested and analyzed in same manner as that of the samples. The mean and standard deviations of the blanks were calculated to determine the method detection limit and method quantification limit. The results are given in Table 3. The MDL and MQL are low enough to detect and determine the selected metals at trace levels in the apple fruits.

\section{Recovery test}

Recovery is one of the most commonly used techniques for validation of the analytical results. The accepted recoveries ranged from $90 \%$ to $110 \%$. The efficiency of the optimized procedure was checked by adding the known concentration of each metal to $0.5 \mathrm{~g}$ sample of apple fruit. The spiked apple fruit samples were digested in triplicate following the same procedure used for digestion of the apple fruit sample. The resulting digest of spiked samples was analyzed for their respective metal contents using MP-AES and percent recoveries were calculated for the fruit samples. Acceptable recoveries in the range of $90.8-106 \%$ were obtained for the determined metals in red apple sample from Arbaminch, Chencha. The results indicated that the optimized procedure is reliable and accurate.

\section{Statistical analysis}

A one-way analysis of variance (ANOVA) and the Pearson correlation among the metals were assessed using a statistical software (SPSS Version 20). The analytical data were analyzed using Microsoft Excel 7.

\section{RESULTS AND DISCUSSION}

\section{Minerals contents in green apple from different areas}

The metal concentrations in green apple fruits from different areas are given in Table 4. Concentration of calcium in green apple fruit from South Africa is higher than the concentration of calcium in Ankober and Wollega green apple fruits. The concentration in the green apple fruits from South Africa, Ankober and Wollega were 36275, 1125, $1065 \mathrm{mg} / \mathrm{kg}$, respectively. The concentration of magnesium in sample from South Africa is higher than magnesium concentration in green apple fruits from Wollega and Ankober. The concentration of magnesium were 153, 71.2, $27 \mathrm{mg} / \mathrm{kg}$, respectively for South Africa, Wollega and Ankober.

The concentration of iron in green apple fruits from South Africa is higher than in the green apple fruit from Ankober and Wollega. The concentration of iron were $276,162,103 \mathrm{mg} / \mathrm{kg}$, respectively, in the green apple fruits from South Africa, Ankober and Wollega. The concentration of aluminum in green apple fruit from South Africa is higher than in the samples from Ankober and Wollega. Their mean concentration of $\mathrm{Al}$ were 129, 88.1, $77.8 \mathrm{mg} / \mathrm{kg}$, respectively from the samples from South Africa, Ankober and Wollega. Concentration of zinc in green apple fruit from South Africa is higher than in the samples from Wollega and Ankober. Their concentration were 73.6, 49.7, $41.3 \mathrm{mg} / \mathrm{kg}$, respectively from the samples from South Africa, Wollega and Ankober. The concentrations of manganese in green apple from the three different places were almost the same. Their concentration were 13.5, 13.5, $13.7 \mathrm{mg} / \mathrm{kg}$, respectively in the green apple fruit from Ankober, South Africa and Wollega.

Concentration of cobalt in the green apple fruits from Ankober and South Africa are the same and Wollega green apple fruits have lower concentration of Co than in the samples from other two different places. Numerically green apple fruits from Ankober and South Africa showed $2.48 \mathrm{mg} / \mathrm{kg}$ Co while Co concentration in the sample from Wollega was $1.85 \mathrm{mg} / \mathrm{kg}$. The content of copper in green apple fruit from Ankober is higher than sample from South Africa and Wollega. The concentrations of copper in the samples from Ankober, South Africa and Wollega were 6.56, $5.77,5.13 \mathrm{mg} / \mathrm{kg}$. Nickel in South Africa green apple fruit showed higher concentration than Ankober and Wollega. Their concentration were 2.37, 1.33, $1.38 \mathrm{mg} / \mathrm{kg}$ respectively in the samples from Ankober, South Africa and Wollega. Chromium concentration obtained in the sample from South Africa > Wollega > Ankober. Their concentration were 10.04, 8.57, $6.15 \mathrm{mg} / \mathrm{kg}$ in the samples from South Africa, Ankober and Wollega, respectively.

The metal content obtained in Ankober green apple fruit was in the decreasing order of $\mathrm{Ca}>\mathrm{Fe}>\mathrm{Al}>\mathrm{Zn}>\mathrm{Mg}>\mathrm{Cu}>$ 
$\mathrm{Cr}>\mathrm{Co}>\mathrm{Ni}$. South Africa green apple sample contain the metal content in the order of $\mathrm{Ca}>\mathrm{Fe}>\mathrm{Mg}>\mathrm{Al}>\mathrm{Zn}>\mathrm{Mn}>$ $\mathrm{Cr}>\mathrm{Cu}>\mathrm{Co}>\mathrm{Ni}$ and Wollega green apple fruit content of metal was in the decreasing order of $\mathrm{Ca}>\mathrm{Fe}>\mathrm{Al}>\mathrm{Mg}>\mathrm{Zn}$ $>\mathrm{Mn}>\mathrm{Cr}>\mathrm{Cu}>\mathrm{Co}>\mathrm{Ni}$.

\section{Minerals contents in red apple from different areas}

The concentrations of metals in red apple fruits from Arbaminch, Israel and Wollega are given in Table 5. Table 5 shows that the calcium concentration in Arbaminch red apple fruit is higher than in red apple fruits from Wollega and Israel. Their concentration were 36143, 2444, 1013 $\mathrm{mg} / \mathrm{kg}$, respectively. Red apple fruit from Israel have higher magnesium concentration than in the red apple fruits from Wollega and Arbaminch. Wollega and Arbaminch red apple samples showed almost the same concentration and were 78.7 and $78.3 \mathrm{mg} / \mathrm{kg}$, respectively.

The concentration of iron in the red apple fruit from Israel is higher than in the samples from Arbaminch and Wollega. The mean concentration were 241, 129, 123 $\mathrm{mg} / \mathrm{kg}$ in the samples from Israel, Arbaminch and Wollega, respectively. Concentration of aluminum in red apple fruit from Wollega is higher than in the sample from Arbaminch and Israel. Their mean concentration were 89.6, 68.9, 52.5 $\mathrm{mg} / \mathrm{kg}$, respectively. Zinc concentration in the red apple fruits from the three place were $54.4,51.3,47.4 \mathrm{mg} / \mathrm{kg}$, respectively. Concentration of manganese in the red apple fruits from Wollega is higher than in the sample from Arbaminch and Israel. The concentration of manganese is in the order of $16.3,15.3,11.5 \mathrm{mg} / \mathrm{kg}$, respectively. Cobalt content in red apple fruits collected from the three places were in the order of Arbaminch > Israel > Wollega. Their concentration were $2.28,2.35,1.70 \mathrm{mg} / \mathrm{kg}$, respectively. Copper content in the red apple fruits from the three places were in the decreasing order from Wollega, Arbaminch and Israel, respectively. Mean concentration of nickel in the red apple fruits from Israel is higher than sample from Wollega and Arbaminch. Their mean concentration is 7.66, 1.78, $1.43 \mathrm{mg} / \mathrm{kg}$, respectively. Mean concentration of chromium in the red apple fruits from Arbaminch is higher than in the red apple fruits from Israel and Wollega. Both samples of red apple from Israel and Wollega have almost the same concentration.

The concentration of metal content in red apple fruit from Arbaminch is in order of $\mathrm{Ca}>\mathrm{Fe}>\mathrm{Mg}>\mathrm{Al}>\mathrm{Zn}>$ $\mathrm{Mn}>\mathrm{Cu}>\mathrm{Cr}>\mathrm{Co}>\mathrm{Ni}$. In the red apple fruit from Israel the order of metal content is $\mathrm{Ca}>\mathrm{Fe}>\mathrm{Mg}>\mathrm{Zn}>\mathrm{Al}>\mathrm{Mn}>\mathrm{Ni}>$ $\mathrm{Cr}>\mathrm{Cu}>\mathrm{Co}$ and the order of metal content in Wollega red apple fruit is $\mathrm{Ca}>\mathrm{Fe}>\mathrm{Al}>\mathrm{Mg}>\mathrm{Zn}>\mathrm{Mn}>\mathrm{Cu}>\mathrm{Cr}>\mathrm{Ni}>$ Co.

\section{Comparison of minerals in the green and red apple}

The comparison (Table 6) showed that most metals have higher concentration in green apple fruit than in red apple fruit. Concentration of calcium in green apple fruit is slightly higher than red apple fruit. In green apple fruit its range is $1065-36275 \mathrm{mg} / \mathrm{kg}$ but in red apple fruit its range is $1013-36143 \mathrm{mg} / \mathrm{kg}$. Green apple fruit have higher aluminum concentration range than in red apple fruit, in green apple fruit its range is $77.8-129 \mathrm{mg} / \mathrm{kg}$ but in red apple fruit its mean concentration range is 52.5- 89.6 $\mathrm{mg} / \mathrm{kg}$. Green apple fruit have lower nickel concentration than in the red apple fruit. All the others have varied concentration range.

\section{The correlation coefficient analysis}

Pearson's correlation coefficient was used to investigate correlations between metal concentration in the green apple fruit and red apple fruit. A high correlation coefficient near +1 or -1 indicate good relationship between two variables and the correlation coefficient around zero means no relationship between them at a significant level of $0.05 \%$ level. It can be strongly correlated for $r>0.7$, where as $r$ values between 0.5 to 0.7 shows moderate correlation between two different parameters (Miller and Miller, 2005). The correlation coefficients between metals in green apple fruit reflected very good correlation, medium correlation and weak correlation (Table 7). Correlations of metals between the following $\mathrm{Ca} / \mathrm{Mg}, \mathrm{Ca} / \mathrm{Fe}, \mathrm{Ca} / \mathrm{Al}, \mathrm{Ca} / \mathrm{Zn}$, $\mathrm{Ca} / \mathrm{Cr}, \mathrm{Ca} / \mathrm{Ni}, \mathrm{Mg} / \mathrm{Fe}, \mathrm{Mg} / \mathrm{Al}, \mathrm{Mg} / \mathrm{Cr}, \mathrm{Mg} / \mathrm{Ni}, \mathrm{Fe} / \mathrm{Mn}, \mathrm{Fe} / \mathrm{Al}$, $\mathrm{Fe} / \mathrm{Zn}, \mathrm{Fe} / \mathrm{Co}, \mathrm{Mn} / \mathrm{Cu}, \mathrm{Cu} / \mathrm{Co}, \mathrm{Al} / \mathrm{Ni}, \mathrm{Zn} / \mathrm{Cr}, \mathrm{Zn} / \mathrm{Ni}$ and $\mathrm{Cr} / \mathrm{Ni}$ are very strong. Correlation between the metal of $\mathrm{Ca} / \mathrm{Cu}$, $\mathrm{Ca} / \mathrm{Co}, \mathrm{Fe} / \mathrm{Cr}, \mathrm{Cu} / \mathrm{Cr}, \mathrm{Al} / \mathrm{Cr}$ and $\mathrm{Al} / \mathrm{Co}$ are moderate. $\mathrm{Ca} / \mathrm{Mn}$, $\mathrm{Mg} / \mathrm{Cu}, \mathrm{Mn} / \mathrm{Zn}$ and $\mathrm{Cu} / \mathrm{Ni}$ have weak negative correlation relationships. $\mathrm{Ca} / \mathrm{Mn}$ and $\mathrm{Mn} / \mathrm{Al}$ have moderate negative correlation relationships. $\mathrm{Mg} / \mathrm{Zn}$ have perfect positive correlation relationships and $\mathrm{Mn} / \mathrm{Co}$ have perfectively negative correlation relationships.

The correlation coefficients of the metals in red apple fruit are given in Table 8. Pearson correlation coefficient shows strong correlation, moderate correlation and weak correlation relationships of metals in red apple fruit. $\mathrm{Ca} / \mathrm{Cr}, \mathrm{Mg} / \mathrm{Fe}, \mathrm{Mg} / \mathrm{Zn}, \mathrm{Mg} / \mathrm{Ni}, \mathrm{Fe} / \mathrm{Zn}, \mathrm{Fe} / \mathrm{Ni}, \mathrm{Mn} / \mathrm{Cu}$, $\mathrm{Mn} / \mathrm{Al}, \mathrm{Cu} / \mathrm{Al}, \mathrm{Zn} / \mathrm{Ni}$ have strong positive correlation relationships. $\mathrm{Ca} / \mathrm{Zn}, \mathrm{Mg} / \mathrm{Mn}, \mathrm{Mg} / \mathrm{Cu}, \mathrm{Mg} / \mathrm{Al}, \mathrm{Fe} / \mathrm{Mn}, \mathrm{Fe} / \mathrm{Cu}$, $\mathrm{Fe} / \mathrm{Al}, \mathrm{Mn} / \mathrm{Zn}, \mathrm{Cu} / \mathrm{Co}, \mathrm{Cu} / \mathrm{Ni}, \mathrm{Al} / \mathrm{Co}, \mathrm{Al} / \mathrm{Ni}, \mathrm{Zn} / \mathrm{Co}$ have strong negative correlation relationships. $\mathrm{Ca} / \mathrm{Co}$ and $\mathrm{Cr} / \mathrm{Co}$ have positive moderate correlation relationships. $\mathrm{Ca} / \mathrm{Mg}$, $\mathrm{Mg} / \mathrm{Cr}, \mathrm{Mn} / \mathrm{Co}, \mathrm{Cu} / \mathrm{Cr}, \mathrm{Cr} / \mathrm{Ni}$ have negative moderate correlation relationships. The correlation relationship between $\mathrm{Ca} / \mathrm{M} \mathrm{n}, \mathrm{Mg} / \mathrm{Co}, \mathrm{Fe} / \mathrm{Co}, \mathrm{Mn} / \mathrm{Cr}$ and $\mathrm{Co} / \mathrm{Ni}$ have weak positive relationship and $\mathrm{Ca} / \mathrm{Mn}, \mathrm{Ca} / \mathrm{Cu}, \mathrm{Ca} / \mathrm{Al}, \mathrm{Fe} / \mathrm{Cr}$, $\mathrm{Cu} / \mathrm{Zn}, \mathrm{Al} / \mathrm{Zn}, \mathrm{Al} / \mathrm{Cr}$ and $\mathrm{Zn} / \mathrm{Co}$ have weak negative correlation relationship.

\section{Analysis of variance (ANOVA)}

In this study, samples of apple fruits were collected randomly from six different places. During these processes a number of random errors may be introduced in each aliquot and in each replicate measurement. Therefore 
depending upon the type and nature of results, analysis of variance (ANOVA) is used to check whether there is contribution from these random errors for the difference in results of analysis or not (DuPoy and Gitlin, 2016). One-way analysis of variance (ANOVA) was used to perform the statistical analysis with apple fruit as independent and concentration of the metals as dependent variable to test whether there are significant differences between means of each plant sample. The results of the analysis are depicted in Tables 9 and 10. the ability of variety of apple plant to accumulate different amount level of metals caused by differences in geographical locations and climatic conditions.

\section{Comparison of minerals with reported studies}

Comparison of metal concentration in apple fruit with other literature values is summarized in Table 11 . The results indicate that difference between mean concentrations of metals from this research and other research reported in

Table 11: Comparison of metal concentration in apple fruits with other literature values

\begin{tabular}{cccccccccc}
\hline & M106 & M26 & M9 & AGAF & SAGAF & WGAF & ARAF & IRAF \\
\hline $\mathrm{M}$ & Mean \pm SD & Mean \pm SD & Mean \pm SD & Mean \pm SD & Mean \pm SD & Mean \pm SD & Mean \pm SD & Mean \pm SD & Mean \pm SD \\
\hline $\mathrm{Ca}$ & - & - & - & $1125 \pm 104$ & $36275 \pm 04$ & $1065 \pm 60$ & $36143 \pm 353$ & $1013 \pm 35.5$ & $2444 \pm 140$ \\
$\mathrm{Mg}$ & - & - & - & $27.0 \pm 1.7$ & $153 \pm 10$ & $71.2 \pm 6.5$ & $78.3 \pm 4.75$ & $139 \pm 4.65$ & $78.7 \pm 6.47$ \\
$\mathrm{Fe}$ & $3.36 \pm 1.79$ & $3.23 \pm 0.74$ & $4.13 \pm 2.59$ & $162 \pm 12$ & $276 \pm 10$ & $103 \pm 6$ & $129 \pm 9.94$ & $241 \pm 15.05$ & $123 \pm 5.19$ \\
$\mathrm{Mn}$ & - & - & - & $13.5+1.1$ & $13.5 \pm 0.9$ & $13.7 \pm 0.7$ & $15.3 \pm 0.74$ & $11.5 \pm 1.04$ & $16.3 \pm 1.5$ \\
$\mathrm{Cu}$ & $0.98 \pm 0.32$ & $0.78 \pm 0.56$ & $0.93 \pm 0.87$ & $6.56 \pm 1.06$ & $5.77 \pm 0.46$ & $5.13 \pm 0.3$ & $7.94 \pm 0.23$ & $4.11 \pm 0.24$ & $12.6 \pm 1.13$ \\
$\mathrm{Al}$ & - & - & - & $88.1 \pm 8.1$ & $129 \pm 10.15$ & $77.8 \pm 4.01$ & $68.9 \pm 2.11$ & $52.5 \pm 1.53$ & $89.6 \pm 8.15$ \\
$\mathrm{Zn}$ & $0.88 \pm 0.44$ & $0.74 \pm 0.6$ & $0.31 \pm 0.13$ & $41.3 \pm 3.67$ & $73.6 \pm 2.52$ & $49.7 \pm 4.13$ & $47.4 \pm 1.89$ & $54.4 \pm 4.51$ & $51.3 \pm 3.77$ \\
$\mathrm{Cr}$ & $1.27 \pm 0.63$ & $0.99 \pm 0.58$ & $0.49 \pm 1.37$ & $6.15 \pm 0.13$ & $10 \pm 0.79$ & $8.57 \pm 0.61$ & $7.14 \pm 0.18$ & $6.57 \pm 0.61$ & $6.57 \pm 0.41$ \\
$\mathrm{Co}$ & - & - & - & $2.48 \pm 0.13$ & $2.48 \pm 0.20$ & $1.85 \pm 0.10$ & $2.35 \pm 0.17$ & $2.28 \pm 0.23$ & $1.70 \pm 0.04$ \\
$\mathrm{Ni}$ & $0.28 \pm 0.07$ & $0.18 \pm 0.17$ & $0.19 \pm 0.27$ & $1.33 \pm 0.07$ & $2.37 \pm 0.05$ & $1.38 \pm 0.11$ & $1.43 \pm 0.08$ & $7.66 \pm 0.51$ & $1.78 \pm 0.12$ \\
$\mathrm{~Pb}$ & $0.51 \pm 0.34$ & $0.38 \pm 0.26$ & $0.31 \pm 0.21$ & ND & ND & ND & ND & ND & ND \\
$\mathrm{Cd}$ & $0.009 \pm 11.1$ & $0.08 \pm 0.58$ & $0.003 \pm 3.3$ & ND & ND & ND & ND & ND \\
\hline
\end{tabular}

M106, M26 and M9 are the sample code of Resmije et al. (2019). AGAF = Ankober green apple fruit, SAGAF = South Africa green apple fruit, $\mathrm{WGAF}=$ Wollega green apple fruit, $\mathrm{ARAF}=$ Ankober red apple fruit, IRAF = Israel red apple fruit, WRAF = Wollega red apple fruit.

Table 12: Comparison of results of the present study metals concentration with WHO/FAO (2009)

\begin{tabular}{|c|c|c|c|c|c|c|c|}
\hline \multirow[t]{2}{*}{ Parameters } & & \multicolumn{5}{|c|}{ Metals concentration by $\mu \mathrm{g} / \mathrm{kg}$ or $\mathrm{mg} / \mathrm{kg}$} & \multirow[b]{2}{*}{$\mathrm{Cd}$} \\
\hline & & $\mathrm{Cu}$ & $\mathrm{Zn}$ & Co & $\mathrm{Ni}$ & $\mathrm{Pb}$ & \\
\hline \multicolumn{2}{|l|}{ WHO/FAO } & $0.205 \mathrm{mg}$ & $0.288 \mathrm{mg}$ & $45.24 \mu \mathrm{g}$ & $0.116 \mathrm{mg}$ & $36.8 \mu \mathrm{g}$ & $5.54 \mu \mathrm{g}$ \\
\hline \multirow[t]{3}{*}{ Green } & ANAG & $0.512 \mathrm{mg}$ & $3.22 \mathrm{mg}$ & $193 \mu \mathrm{g}$ & $0.103 \mathrm{mg}$ & - & - \\
\hline & SAAG & $0.450 \mathrm{mg}$ & $5.74 \mathrm{mg}$ & $193 \mu \mathrm{g}$ & $0.185 \mathrm{mg}$ & & - \\
\hline & WAG & $0.400 \mathrm{mg}$ & $3.88 \mathrm{mg}$ & $144 \mu \mathrm{g}$ & $0.108 \mathrm{mg}$ & - & - \\
\hline \multirow[t]{3}{*}{ Red apple } & AAR & $0.619 \mathrm{mg}$ & $3.70 \mathrm{mg}$ & $183 \mu \mathrm{g}$ & $0.112 \mathrm{mg}$ & - & - \\
\hline & IAR & $0.321 \mathrm{mg}$ & $4.24 \mathrm{mg}$ & $178 \mu \mathrm{g}$ & $0.597 \mathrm{mg}$ & - & - \\
\hline & WAR & $0.983 \mathrm{mg}$ & $4.00 \mathrm{mg}$ & $133 \mu \mathrm{g}$ & $0.139 \mathrm{mg}$ & - & - \\
\hline
\end{tabular}

The results depicted in Table 9 show that there is a significant difference ( $\mathrm{p} \geq 0.05$ ) for copper, aluminum and cobalt. All the other metals have no significance difference. Their $p$-value was $p \leq 0.05$. This significance difference and insignificance difference arise from the differences in soil composition and environmental affect.

The results of analysis in Table 10 show that there is a significance difference between the mean of metals in red apple. Copper, zinc, chromium and cobalt exhibited significance differences $\mathrm{p} \geq 0.05$. The other metals have insignificance differences. This may be due to variation in the literature. Mean concentration of iron in the samples of present study is $162,276,103 \mathrm{mg} / \mathrm{kg}$ for green apple fruit and $129,241,123 \mathrm{mg} / \mathrm{kg}$ for red apple fruit, respectively. But the study done by Resmije et al. (2 019) indicates 3.36, $3.23,4.13 \mathrm{mg} / \mathrm{kg}$ of iron in apple fruits while the concentration $6.56,5.77,5.13 \mathrm{mg} / \mathrm{kg}$ of copper in the green apple fruits and 7.94, 4.11 and $12.6 \mathrm{mg} / \mathrm{kg}$ of copper in the red apple fruits. The study of Resmije et al. (2019) showed copper concentration of $0.98,0.78,0.93 \mathrm{mg} / \mathrm{kg}$, respectively. The zinc concentration in the green apple of this research is $41.3,73.6,49.7 \mathrm{mg} / \mathrm{kg}$ and in the red apple 
sample $47.4,54.4,51.3 \mathrm{mg} / \mathrm{kg}$ but the literature study by Rismije et al. (2019) indicates $0.88,0.74,0.31 \mathrm{mg} / \mathrm{kg}$, respectively.

Chromium concentration in green and red apple fruits of the present study is higher than results from study of Rismije et al. (2019). The mean concentration for nickel obtained in the green and red apple fruits of this research is $1.33,2.37,1.38 \mathrm{mg} / \mathrm{kg}$ and 1.43, 7.66, $1.78 \mathrm{mg} / \mathrm{kg}$, respectively, but the literature study by Resmije et al. (2019) are $0.28,0.18,0.19 \mathrm{mg} / \mathrm{kg}$, respectively. In the present study lead and cadmium were not detected while in the study of Resmije et al. (2019) mean concentration of lead $0.51,0.38,0.31 \mathrm{mg} / \mathrm{kg}$ and cadmium $0.009,0.08$ and $0.003 \mathrm{mg} / \mathrm{kg}$, respectively, were reported.

\section{Comparison of minerals with WHO/FAO standards}

Table 12 summarizes the comparison between the metal concentrations in the apple fruits of present study with the metal concentration in the apple fruits of WHO/FAO report in 2009. The exposure of consumers and the related health risks are usually expressed in terms of the provisional tolerable daily intake (PTDI). The FAO/WHO (2009) have set a limit for the heavy metal intake based on body weight for an average adult, namely, $60 \mathrm{~kg}$ body weight. The average diet per person per day of fruit is assumed to be $78 \mathrm{~g}$. The contribution of heavy metal intake for an average human being from the fruit diet is $\mathrm{Cu} 0.205 \mathrm{mg}, \mathrm{Zn}$ $0.288 \mathrm{mg}$, Co $45.24 \mu \mathrm{g}$, Ni $0.116 \mathrm{mg}$, Pb $36.89 \mu \mathrm{g}$, Cd $5.54 \mu \mathrm{g}$, respectively. Apple fruits of the present study are free from the lead and cadmium. The two metals were not detected in any of the six apple fruit samples. Nickel contents in three apple fruit samples are comparable with the WHO/FAO recommended value while its concentration is higher in the other three samples. Copper, zinc and cobalt in all the six apple fruit samples of the present study are higher than the recommended values of WHO/FAO.

\section{CONCLUSIONS}

This study determined two macro essential metals (Mg and $\mathrm{Ca}$ ), eight micro essential metals ( $\mathrm{Fe}, \mathrm{Mn}, \mathrm{Cu}, \mathrm{Al}, \mathrm{Zn}, \mathrm{Cr}, \mathrm{Co}, \mathrm{Ni}$ ) and two toxic or non-essential metals $(\mathrm{Pb}$ and $\mathrm{Cd})$ in green and red apple fruits which were collected from different places using MP-AES. The level of essential metals were in the order: $\mathrm{Ca}(1065-36275)>\mathrm{Fe}(103-276)>\mathrm{Al}(77.8-129)>$ $\mathrm{Zn}$ (41.3-73.6) > Mg (27-153) > Mn (13.5-13.7) > Cr (6.15$10.04)>\mathrm{Cu}(5.13-6.56)>\mathrm{Co}(1.85-2.48) \mathrm{mg} / \mathrm{kg}$ in the green apple fruits and $\mathrm{Ca}(1013-36143)>\mathrm{Fe}(123-241)>\mathrm{Mg}$ (78.3139) > Al (52.5-89.6) > $\mathrm{Zn}(47.4-54.4)>\mathrm{Mn}(11.5-16.3)>\mathrm{Cr}$ $(6.57-7.14)>\mathrm{Cu}(4.11-12.6)>\mathrm{Co}(1.70-2.35)>\mathrm{Ni}(1.43-7.66)$ $\mathrm{mg} / \mathrm{kg}$ in the red apple fruits. The non-essential toxic metals $\mathrm{Cd}$ and $\mathrm{Pb}$ were not detected in any of the apple fruits by MPAES. Comparable results were found with some of the values reported in the literature which indicate some difference due to differences in soil properties and other environmental conditions. Statistical analysis by using one way ANOVA indicated that there is a significance difference in mean concentration of metals under investigation. $\mathrm{Cu}, \mathrm{Al}$ and $\mathrm{Co}$ exhibited significance differences among the green apple fruits collected from different sites while in the red apple fruits collected from different sites there is a significance difference in the contents of $\mathrm{Fe}, \mathrm{Mn}, \mathrm{Cu}, \mathrm{Zn}, \mathrm{Cr}$ and $\mathrm{Co}$.

\section{REFERENCES}

Aregahegn, A., Chandravanshi, B.S., Atlabachew, M., 2013. Mineral contents of fruits of cactus pear (Opuntia ficus indica) grown in Ethiopia. Acta Horticulture (ISHS) 979, 117-126.

Brock, K.E., Berry, G., Mock, P., Lennan, R.M., Truswell, A.S., Brinton, L.A., 1988. Brinton Nutrients in diet and plasma and risk of in situ cervical cancer. Journal of National Cancer Institute 80, 580-585.

Casero, T., Adriana, L., Benavides, A.L., Inmaculada Recasens, I., 2009. Interrelation between fruit mineral content and pre-harvest calcium treatments on 'golden smoothee' apple quality. Journal of Plant Nutrition 33, 27-37.

Dai, H., Yoshimatsu, T.F., Long, M., 2006. Retrogene movement within and between chromosomes in the evolution of Drosophila genomes. Genetics 385, 96-102.

DuPoy, E., Gitlin, L.N., 2016. 1998. Introduction to research: Understanding and applying multiple strategies, $2^{\text {nd }}$ edition. St Louis: Mosby Inc. GLASER, B.G. 1992. Basics of Grounded Theory Analysis. Mill Valley CA: Sociology Press.

Endalamaw, F.D., Chandravanshi, B.S., 2015. Levels of major and trace elements in fennel (Foeniculum vulgari Mill.) fruits cultivated in Ethiopia. Springer Plus 4, 5.

Fatih, E.R., Özcan, M.M., 2010. Chemical compositional properties and mineral contents of some apple cultivars. South Western Journal of Horticulture, Biology and Environment 1(2), 121-131.

Feldman, E.B., 2001. Fruits and vegetables and the risk of stroke. Nutrition Reviews 59, 24-27.

Hagos, M., Chandravanshi, B.S., 2016. Levels of essential and non-essential metals in fenugreek seed (Trigonella Foenum-Graecum L.) cultivated in different parts of Ethiopia. Brazilian Journal of Food Technology 19, e2015059.

FAO/WHO, 1999. Joint FAO/WHO Expert Committee on Food Additives 1999. Summary and conclusions, in Proceedings of the 53rd Meeting Joint FAO/WHO Expert Committee on Food Additives, Rome, Italy, 827645. DOI: 10.5402/1999/827645.

Kent, K., Charlton, K., Roodenrys, S., Batterham, M., Potter, J., Traynor, V., Gilbert, H., Morgan, O., Richards, R., 2017. Consumption of anthocyanin-rich cherry juice for 12 weeks improves memory and cognition in older adults with mild-to-moderate dementia. European Journal of Nutrition 56(1), 333-341.

Lee, C.Y., 2012. Common nutrients and nutraceutical quality of apples. New York Fruit Quarterly 20(3), 3-8. 
Leis, L., Lepik, A., Lepiku, T., Karus, A., 2003. Mineral content of apple fruits and leaves. AGRIS 13(3), 176-181.

Mekassa, B., Chandravanshi, B.S., 2015. Levels of selected essential and non-essential metals in seeds of korarima (Aframomum corrorima) cultivated in Ethiopia. Brazilian Journal of Food Technology 18, 102-111.

Miller, J.N., Miller, J.C., 2005. Statistics and chemometrics for analytical chemistry, $5^{\text {th }}$ edition, Pearson Practice Hall, England.

Nahar, N., Rahaman, S., Mosiihuzzaman, M., 1990. Analysis of carbohydrates in seven edible fruits of Bangladesh. Journal of the Science of Food and Agriculture 5, 185192.

Nava, G., Ciotta, M.N., Pasa, M., Boneti, J.I., 2018. Mineral composition of leaves and fruits of apple 'Fuji' on different rootstocks in the region of São Joaquim-SC. Revista Brasileira de Fruticultura 40(2), 1-10.

Resmije, I., Endrit, K., Lulzim, M., 2019. Distribution of heavy metals in apple tissues grown in the soils of industrial area. Journal of Ecological Engineering 20(3), 57-66.

Sachini, R., Steffens, C.A., de Martin, M.S., Schveitzer, B., Fenili, C.L., José Luiz Petri, J.L., 2020. Mineral contents in the skin and flesh of fruits of apple cultivars. Revista Brasileira de Fruticultura 42(2), e-572.

Tasnim, F., Hossain, M.A., Nusrath, S., Hossain, M.K., Lopa, D., Haque, K.M.F., 2010. Quality assessment of industrially processed fruit juices available in Dhaka City, Bangladesh. Malaysian Journal of Nutrition 16(3), 431438.

Webster, D.H., 1981. Mineral composition of apple fruits. Relationships between and within peel, cortex and whole fruit samples. Canadian Journal of Plant Science 6l, 73-85.

Yami, S.G., Chandravanshi, B.S., Wondimu, T., Abuye, C., 2016. Assessment of selected nutrients and toxic metals in fruits, soils and irrigation waters of Awara Melka and Nura Era farms, Ethiopia. Springer Plus 5, 747.

Visit us at: http://bosaljournals.com/chemint/ Submissions are accepted at: editorci@bosaljournals.com 